stratigraphic domains in the Sergipano and Sul-Alagoano belts of the Borborema Province, northeastern Brazil. In the first belt, besides the well-known domains of Macururé, Vaza Barris and Estância, two others are recognized: Rio Coruripe and Viçosa. The Rio Coruripe domain contains rift-related volcano-sedimentary sequence, metabasalts and iron-formation bearing, intruded by mafic-ultramafic layered complex. The Viçosa domain consists of a metamorphosed volcano-sedimentary sequence; Mesoproterozoic plutonic rocks with $1.57 \mathrm{Ga}(\mathrm{U}$ $\mathrm{Pb}$ ) and $1.0 \mathrm{Ga}(\mathrm{Rb}-\mathrm{Sr})$ and Neoproterozoic peraluminous granitoids with $0.75 \mathrm{Ga}(\mathrm{Rb}-\mathrm{Sr})$ and calc-alkaline granites with $0.59 \mathrm{Ga}(\mathrm{U}-\mathrm{Pb})$. Carbonates from the Olhos d'Água Fm. of the Vaza Barris domain have an isotopic signature similar to that of the Bambuí group, distinct of the Jacoca carbonates (Miaba group). The Palestina Fm., at the base of the Olhos d'Água Fm., encloses Miaba group deformed pebbles. The last one, chronocorrelated to the Macururé group, is Mesoproterozoic in age. The Sul-Alagoano belt has two domains. The Canindé-Marancó domain hosts flysch-type volcanoclastic sedimentation; calc-alkaline volcanic rocks with $1.04 \mathrm{Ga}(\mathrm{U}-\mathrm{Pb}$; TDM=1.2 Ga); tonalitic $(\mathrm{TDM}=1.75 \mathrm{Ga})$ and peraluminous (TDM=1.66 Ga) Mesoproterozoic plutonic rocks; early peraluminous Neoproterozoic plutonic rocks (U-Pb; 0,715 Ga); podiform chromitebearing ultrabasic rocks that could be mantle-derived ophiolitic slices. The Pernambuco-Alagoas domain shows a characteristic tonalitic-dominant Mesoproterozoic plutonism (TDM=1.3 Ga); fracture-bound late shoshonitic/peralkaline and peraluminous magmatism $(0.58 \mathrm{Ga}, \mathrm{Rb}-\mathrm{Sr}$ and $\mathrm{TDM}=1.0 \mathrm{Ga})$.

The Sergipano belt has rift-related and Atlantic margin Meso/Neoproterozoic platform sedimentation. Basement nucleus (TDM=3.0 Ga), granitoids from the Macururé domain with model ages between 1.71 and $1.3 \mathrm{Ga}$ and from Viçosa domain between 0.9 and $2.5 \mathrm{Ga}$, suggest a sialic basement. The Marancó/Canindé calcalkaline volcanics and ophiolites (?) point to the presence of oceanic crust in the Sul-Alagoano belt. Abundant Mesoproterozoic tonalites resemble a thickened Andeantype arc in the Pernambuco/Alagoas domain, with extensional shoshonitic/peralkaline magmatism $(0.58 \mathrm{Ga}, \mathrm{Rb}-$ $\mathrm{Sr})$. There were two stages of amalgamation in the Sergipano and Sul-Alagoano belts: at 1.0 and at $0.75 \mathrm{Ga}$, characterized, respectively, by Caririano- and Brasiliano age peraluminous granitoids. The sutures between belts and their domains are bounded, respectively, by the Belo
Monte/Jeremoabo shear zone and granites, both showing remarkable magnetic anomalies. - ( May 24, 2002 ).

\section{HYDRODYNAMICS OF THE AMAZON BASIN}

Pierre Sabaté

Institut de Recherche et Développement (IRD), Brasília, DF.

Registered under the $\mathrm{CNPq} / \mathrm{IRD}$ convention, the HYBAM project is a model of multi-institutional and international cooperation. It involves the ANA, ANEEL and $\mathrm{UnB}$, as well as researchers from other Brazilian (USPCENA, UFRJ, IBGE, IEPA) Institutions and some neighboring countries (Bolivia, Peru and Equator).

We show here the wide spectrum of collected data on the Amazon River and its affluents, from Tabatinga to the Atlantic Ocean and an extensive view on modelling and applied domains. Complementary approaches are developed to understand hydrologic dynamics related to climatic forcing, sedimentary and geochemical dynamics.

The methodology implements a hydrologic permanent station net. The studies cover an altimetric calibration of the whole hydrologic network, rivers discharge gouges and several parameters to quantify dynamic processes. They encompass the wave tide influence on liquid and sedimentary discharge of the Amazon River and the influence of climatic index on its respective variability. The role played by flood plains on hydrodynamics is studied and inundation dynamics is followed by satellite imagery. Balance between erosion, transfer and depositional processes, from Andean sources to flood plains, is estimated by flux method and the present sedimentation, by geochemical tracers and geochronologic models. Space and time variability of trace element signatures of surface waters is studied to evidence trap areas and speciation risks of some heavy metals related to a historic study of mercury contamination.

One of the scopes is the Amazon river hydrology modeling (climate versus river discharge relation), its hydrodynamics applied to the prediction of water levels, flow velocities and flood plain dynamics, and of its sedimentology (transport capacities and sediment trapping quantification). Modeling will be useful to investigate the impact of anthropic activities (dams, mining, and so on) improve management of water resources, predict floods (cities of Manaus or Santarém) as well as navigability conditions (Madeira River). The research teams are preparing the corresponding GIS-Amazônia for these studies. - ( May 24, 2002 ) . 